\title{
CONCOMITANT PRODUCTION OF PROTEASE AND LIPASE BY BACILLUS LICHENIFORMIS VSG1: PRODUCTION, PURIFICATION AND CHARACTERIZATION
}

\author{
R. Sangeetha ${ }^{1}$, A. Geetha ${ }^{2 *}$, I. Arulpandi ${ }^{3}$ \\ ${ }^{1}$ Department of Biochemistry, Vels University, Chennai, India, 600117 ; ${ }^{2}$ Department of Biochemistry, Bharathi Women's \\ College, Chennai, India, 600 108; ${ }^{3}$ Department of Microbiology, Asan memorial college, Chennai, India, 600100.
}

Submitted: January 13, 2009; Returned to authors for corrections: April 15, 2009; Approved: July 24, 2009.

\begin{abstract}
This study was aimed at producing protease and lipase simultaneously on a common medium by Bacillus licheniformis VSG1, which was isolated from a tannery effluent. The effect of media composition with respect to protein source, lipid source and emulsifier on the production of protease and lipase was analysed. Both those enzymes were produced under optimized conditions like $\mathrm{pH}$, temperature and incubation time. The enzyme mixture comprising of both protease and lipase was purified by ammonium sulphate precipitation, dialysis and gel filtration chromatography to obtain 20-fold pure enzymes. The purified enzyme mixture was characterized to determine the optimum $\mathrm{pH}$ and temperature of protease and lipase, the response of the enzymes to inhibitors, additives and solvents. The molecular weight of both the enzymes was determined as $40 \mathrm{kDa}$ on SDS-PAGE. The concomitant production of protease and lipase and the purification of both the enzymes in a single mixture have industrial significance, as many industrial processes use both protease and lipase together.
\end{abstract}

Key words: Bacillus licheniformis, protease, lipase, concomitant production, purification

\section{INTRODUCTION}

Of all the industrially important enzymes, proteases followed by carbohydrases and lipases have a wide range of applications. Proteases and lipases have great industrial potential and are exploited by many industries. Both these enzymes are widely used in detergents, leather, dairy, baking and pharmaceutical industries. Processes like bating the leather and cleaning slaughter house equipment require a mixture of protease and lipase (18). Thus concomitant production of protease and lipase has industrial significance. Proteases and lipases occur widely in microorganisms, plants and animals
$(15,21)$. Among the microbial sources, bacteria especially Bacillus sp have been exploited for production of proteases and lipases $(6,17)$. There are many reports which have optimized the production of protease and lipase in separate media and very few reports on a mixed media. But no information concerning the purification of the simultaneously expressed protease and lipase is available. Simultaneous expression of protease and lipase will prove to be useful as few industrial processes require the action of both protease and lipase. An elaborate study in the simultaneous expression of both these enzymes becomes necessary because lipase production is found to be influenced by the presence of protease in vivo and 
in vitro. There are reports that suggest the involvement of protease in the down regulation or enhancement of lipase production in Acinetobacter calcoaceticus and Lactobacillus plantarum $(10,14)$. But no such studies have been reported with Bacillus species. The aim of this study is to analyse the influence of media components on the concomitant production of protease and lipase and to purify and characterize both protease and lipase produced on a common production medium using Bacillus licheniformis VSG1.

\section{MATERIALS AND METHODS}

\section{Microorganism}

The bacterial strain, Bacillus licheniformis VSG1 used in this study was isolated from a tannery effluent collected at Chennai, India.

\section{Chemicals and reagents}

All the chemicals used were of analytical grade. Tween 80, tributyrin, p-nitrophenol and all the chemicals used for electrophoresis were purchased from Himedia (Mumbai, India). All the other chemicals used throughout the study were purchased from Qualigens (Mumbai, India).

\section{Medium composition}

Four types of media with varying composition were studied. The production medium A comprised of $0.2 \%$ glucose, $0.5 \%$ yeast extract (YE), $0.5 \%$ tributyrin and $0.5 \%$ sodium chloride, $0.04 \%$ calcium chloride, $0.2 \%$ magnesium chloride, $0.1 \%$ magnesium sulphate and $0.1 \%$ potassium dihydrogen phosphate. The medium B had $0.5 \%$ peptone which replaced YE in medium A. Medium $C$ had $0.5 \%$ Tween 80 added to medium $\mathrm{A}$ and medium $\mathrm{D}$ had $0.5 \%$ Tween 80 added to medium $\mathrm{B}$. The $\mathrm{pH}$ of all the production media was adjusted to 7.0. Enzyme productions were carried out in $250 \mathrm{ml}$ Erlenmeyer flasks with $50 \mathrm{ml}$ of production medium inoculated with $1 \mathrm{ml}$ of an overnight culture. The flasks were incubated at $37^{\circ} \mathrm{C}$ with a constant shaking at 180 rpm for 3 days.

\section{Enzyme assay}

Caseinolytic activity was measured by the photometric method of Rahman et al. (20). One unit (U) of protease activity is equivalent to $0.5 \mu \mathrm{g}$ of tyrosine liberated by $1.0 \mathrm{ml}$ of enzyme solution under the assay conditions. The amount of tyrosine was determined from the tyrosine standard curve. Lipase activity was assayed by the photometric method of Kordel et al. (11). One unit (U) of lipase activity is equal to the amount of enzyme required to liberate $1 \mu$ mole of $\mathrm{p}$-nitrophenol per min under the assay conditions.

\section{Enzyme production and purification}

Enzyme production was carried out using Media $\mathrm{C}(\mathrm{pH}$ 9.0 , temperature $40^{\circ} \mathrm{C}$, incubation time of 30 hours). The production media was centrifuged at $10,000 \mathrm{~g}$ at $4^{\circ} \mathrm{C}$ and the cell free supernatant was the crude enzyme. The proteolytic and lipolytic efficiencies of the crude enzyme were analyzed.

All purification procedures were carried out at $4^{\circ} \mathrm{C}$. The crude enzyme was subjected to $70 \%$ saturated ammonium sulphate precipitation. The precipitate was dissolved in minimal amount of $0.5 \mathrm{M}$ Tris $\mathrm{HCl}$ buffer of $\mathrm{pH} 7.0$, the enzyme activities were assayed and then dialysed extensively against the same buffer. The enzyme activities in the dialysate were assayed. Ten milliliters of the dialysate was loaded on to a Sephadex G100 column which had been pre-equilibriated with $0.5 \mathrm{M}$ Tris $\mathrm{HCl}$ buffer of $\mathrm{pH} 7.0$ containing $0.5 \mathrm{M} \mathrm{NaCl}$ and eluted with the same buffer at a flow rate of $30 \mathrm{ml} / \mathrm{hour}$. All eluted fractions $(2 \mathrm{ml})$ were assayed for enzyme activities and the fractions with high activities were pooled. The pooled fractions were subjected to dialysis against Tris $\mathrm{HCl}$ buffer and the enzyme activities in the dialysates were determined. The dialysates were again loaded on a Sephadex G-100 column preequilibriated with Tris $\mathrm{HCl}$ buffer and eluted with the same buffer.

\section{Characterisation of enzymes}

The optimum $\mathrm{pH}$ of protease and lipase present in the partially purified enzyme mixture was studied over a range of 5.0 to 12.0 by incubating the enzyme mixture for $30 \mathrm{~min}$ with 
casein for protease and tributyrin for lipase. The optimum temperature of both the enzymes was studied by pre-incubating the enzyme mixture for $30 \mathrm{~min}$ at temperatures ranging from $20{ }^{\circ} \mathrm{C}$ to $70^{\circ} \mathrm{C}$.

The effect of additives like SDS, Triton X-100 and $\mathrm{H}_{2} \mathrm{O}_{2}$ on the activity of protease and lipase was studied at a concentration of $2 \% \mathrm{v} / \mathrm{v}$ or $\mathrm{w} / \mathrm{v}$. The residual enzyme activity after an incubation period of 20 min was determined. The effect of organic solvents like hexane, benzene, isopropanol, dimethyl sulphoxide at concentration of $0.5 \% \mathrm{v} / \mathrm{v}$ was studied by incubating the enzyme mixture for 1 hour at $37^{\circ} \mathrm{C}$.

The enzyme mixture was studied for stability by storing it at $-4^{\circ} \mathrm{C}$ and $32^{\circ} \mathrm{C}$ and the activities of protease and lipase were assayed on the $10^{\text {th }}$ and $20^{\text {th }}$ day of storage.

The purified enzyme mixture was subjected to electrophoresis on $10 \%$ acrylamide gel (12) and molecular weight was determined by comparing the relative mobility of the protein band with that of molecular weight markers. Activity staining was performed on $0.1 \%$ copolymerized gelatin as substrate to study protease activity, according to De Azeredo et al. (4). Lipase activity staining was performed using tributyrin agar according to the method of Singh et al. (22).

\section{RESULTS AND DISCUSSION}

Tanneries exploit protease and lipase at various stages of leather processing like soaking and bating. A bacterial strain which could produce protease and lipase concomitantly was expected to colonise in the tannery effluent and a potent strain was screened and isolated. The bacterial strain was identified as Bacillus licheniformis VSG1.

A study was conducted earlier by us on separate production media for protease and lipase production by our isolate (data not shown). Peptone and YE were found to be the best nitrogen sources for protease and lipase production respectively. Tributyrin was found to be the best inducer of lipase. In the present study protease and lipase production on 4 different common production media, A, B, C, D with different compositions were studied to maximize production of both lipase and protease. The results revealed that the enzyme production in medium with $\mathrm{YE}$ as nitrogen source, tributyrin as an inducer of lipase and Tween 80 as emulsifier (medium C) was maximum (Fig 1). Protease production in medium A was equal to that in medium $\mathrm{C}$ but lipase production was $18 \%$ less. The medium with peptone and Tween 80 (media D) produced $20 \%$ less protease and $15 \%$ less lipase. Production study on medium B shows a $22 \%$ reduction in the production of both lipase and protease. Thus YE served to be a better nitrogen source for protease and lipase production than peptone. Joshi et al. (9) have reported a combination of both YE and peptone as a better source for protease production by Bacillus cereus. Moreover, the presence of Tween 80 enhanced the production of enzymes which can be attributed to the emulsifying action of Tween 80 which facilitates better uptake of substrates by the bacteria (Fig 1). Henriette et al. (7) have reported that Tween 80 induces lipase biosynthesis and increases the secretion of the same. Lipase production was enhanced when the substrate formed an emulsion and presented an interfacial area to the enzyme. Tween 80 can also enhance the performance of lipase (13) or can act as an inducer of lipase gene expression (2) or can act as substrate for lipase or esterase (19).

Figure 1. Effect of media components on enzyme production

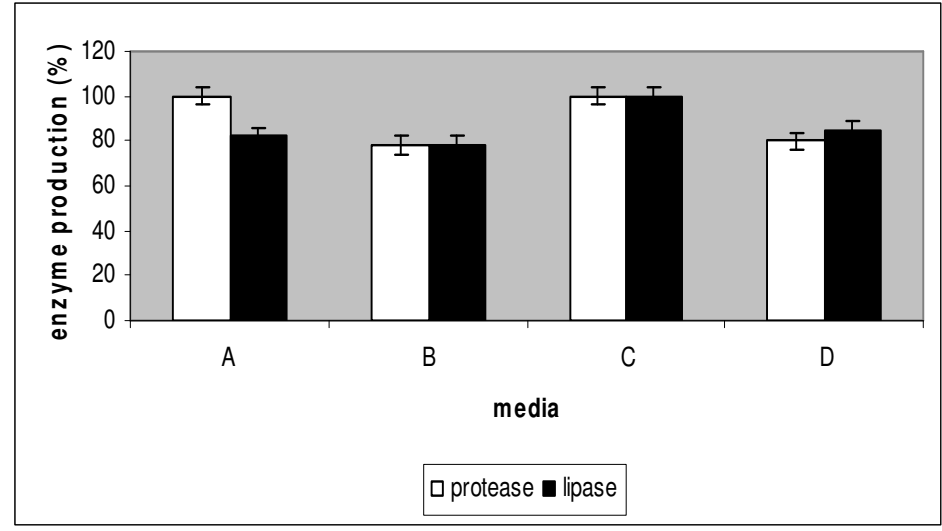

Enzyme activity is the mean of three independent experiments. Enzyme production was carried at $37^{\circ} \mathrm{C}$ for 3 days.

The enzyme production using medium $\mathrm{C}$ was considered as $100 \%$ and production with the media $\mathrm{A}, \mathrm{B}$ and $\mathrm{D}$ are given as \% of enzyme production using media $\mathrm{C}$. 
The crude enzyme was subjected to purification and 20fold purity was obtained after the final purification step. 6-fold purity of both enzymes was obtained after ammonium sulphate precipitation and dialysis. 16-fold purity was obtained after the single step purification on Sephadex G-100 column and the purity enhanced to 20 -fold with the second purification step on Sephadex G-100 column (Table 1).

The purified enzyme mixture consisting of both protease and lipase was characterized. The optimum $\mathrm{pH}$ for the activity of both lipase and protease was found to be 9.0. The enzymes were stable between $\mathrm{pH} 8.0$ and 12.0. Thus these enzymes are as effective as the important detergent enzyme subtilisin Carlberg which as maximum activity between $\mathrm{pH} 8.0$ and 10.0 (8). The optimum temperatures of the enzymes were slightly different, with protease exhibiting maximum activity at $45^{\circ} \mathrm{C}$ and lipase at $55^{\circ} \mathrm{C}$. Both lipase and protease showed very low activities at temperature less than $37^{\circ} \mathrm{C}$ and more than $60^{\circ} \mathrm{C}$. Protease from a thermophilic Bacillus sp too has exhibited a reduction in enzyme activity at temperatures more than $60^{\circ} \mathrm{C}$ (16). Lipase produced by a B.licheniformis MTCC 6824 had $45^{\circ} \mathrm{C}$ as optimum temperature, as reported by Chakraborty and Paul Raj (3). Thus these enzymes are best suited for detergent and leather industries in processes which adopt temperature less than $60^{\circ} \mathrm{C}$ and alkaline $\mathrm{pH}$ (Fig 2). The low optimal temperature for protease and lipase activities are desirable for detergent formulations as reputed branded garment manufacturers recommend washing at normal temperatures (23).

Table1. Purification of protease and lipase produced by Bacillus licheniformis VSG1

a) Protease

\begin{tabular}{lllll}
\hline Purification step & $\begin{array}{c}\text { Total protein } \\
(\mathbf{m g})\end{array}$ & $\begin{array}{c}\text { Specific activity } \\
(\mathbf{U} / \mathbf{m g})\end{array}$ & $\begin{array}{c}\text { Recovery } \\
(\boldsymbol{\%})\end{array}$ & $\begin{array}{c}\text { Purification } \\
(\text { fold })\end{array}$ \\
\hline Crude & 120 & 16.2 & 100 & 1 \\
$\begin{array}{l}\text { Ammonium sulphate } \\
\text { precipitation }\end{array}$ & 44 & 32.0 & 73 & 3 \\
Dialysis & 22 & 53.0 & 61 & 6 \\
Sephadex G-100 & 7.5 & 112.0 & 43 & 16 \\
Sephadex G-100 & 3.6 & 180.5 & 33 & 20 \\
\hline
\end{tabular}

b) Lípase

\begin{tabular}{lcccc}
\hline Purification step & $\begin{array}{c}\text { Total protein } \\
(\mathbf{m g})\end{array}$ & $\begin{array}{c}\text { Specific activity } \\
(\mathbf{U} / \mathbf{m g})\end{array}$ & $\begin{array}{c}\text { Recovery } \\
(\boldsymbol{\%})\end{array}$ & $\begin{array}{c}\text { Purification } \\
\text { (fold) }\end{array}$ \\
\hline Crude & 120 & 13.0 & 100 & 1 \\
$\begin{array}{l}\text { Ammonium sulphate } \\
\text { precipitation }\end{array}$ & 44 & 28.0 & 63 & 3 \\
Dialysis & 22 & 48.6 & 54 & 6 \\
Sephadex G-100 & 7.5 & 101.0 & 39 & 16 \\
Sephadex G-100 & 3.6 & 160.0 & 30 & 20 \\
\hline
\end{tabular}


Figure 2. Effect of $\mathrm{pH}$ (a) and temperature (b) on enzyme activity
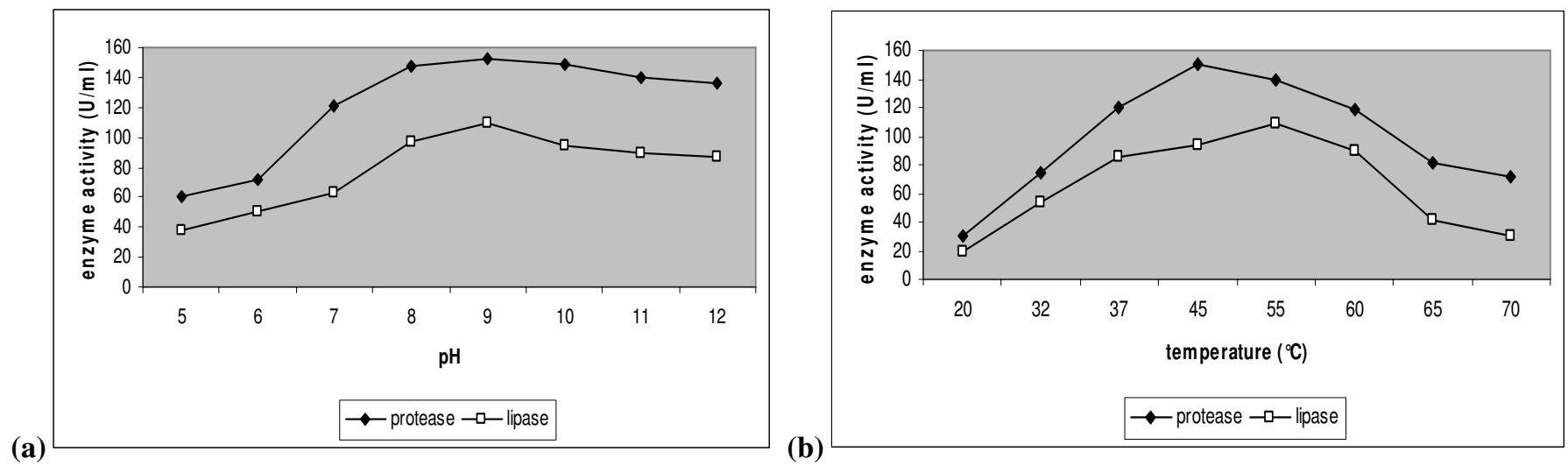

Enzyme activity is the mean of three independent experiments

Response to inhibitors shows that the protease produced by Bacillus licheniformis VSG1 has serine at or near the active site and the lipase produced was dependent on metal ions. The enzymes suffered a minor reduction in activity when treated with $\mathrm{H}_{2} \mathrm{O}_{2}$ and SDS. Ten percent of the activity of both lipase and protease was lost when treated with $\mathrm{H}_{2} \mathrm{O}_{2}$. Protease activity was reduced by $12 \%$ and lipase activity by $9 \%$ in the presence of SDS. Addition of Triton X-100 did not affect enzyme activity. Bayoumi et al. (1) has given a similar report about a lipase suitable for detergent industry. Both lipase and protease were found to be tolerant to solvents. The enzymes exhibited a $7 \%$ reduction in activity in response to hexane and isopropanol, $5 \%$ reduction with DMSO and benzene during the post incubation period (Table 2). The tolerance exhibited by lipase and protease to additives and organic solvents was appreciable and contributes to their better usage as detergent additives. The stability of enzymes in the presence of solvents may be due to the replacement of water molecules in the enzymes by organic molecules and thereby stabilising the structure of the enzyme (5). Thus the enzymes, lipase and protease produced concomitantly by Bacillus licheniformis VSG1 could be exploited for industrial purposes. Protease and lipase produced by different organisms but used as a mixture have been patented and used (18). The enzymes were found to be stable during their storage at -4 and $32^{\circ} \mathrm{C}$ with only a decrease by $4 \%$ in protease activity and $5 \%$ in lipase activity (Table 3 ). Lipase produced by Bacillus licheniformis VSG1 was thus found to be resistant to proteolysis. Involvement of proteolytic activity in the processing of extracellular lipase was investigated earlier and in vitro studies on effect of proteases on lipases showed that lipolytic activity was positively affected by acid proteases (14).

Table 2. Effect of inhibitors, additives and organic solvents on the activity of protease and lipase

\begin{tabular}{lcc}
\hline \multicolumn{1}{c}{ Reagents } & Activity of protease (\%) & Activity of lipase (\%) \\
\hline None & 100 & 100 \\
Inhibitors & 20 & \\
PMSF & 100 & 99 \\
EDTA & 100 & 48 \\
Phenanthroline & 100 & 40 \\
Dithiothreitol & 100 & 100 \\
Iodoacetate & & 100 \\
Additives & 78 & \\
SDS & 99 & 91 \\
Triton X-100 & 90 & 100 \\
$\mathrm{H}_{2} \mathrm{O}_{2}$ & & 90 \\
Organic solvents & 93 & 93 \\
Hexane & 95 & 94 \\
Benzene & 93 & 94 \\
Isopropanol & 95 & 95 \\
Dimethyl sulphoxide & &
\end{tabular}


Table 3. Heat stability of protease and lipase

\begin{tabular}{lccc}
\hline Temperature & Day & $\begin{array}{c}\text { Activity of protease } \\
(\mathbf{U} / \mathbf{m l})\end{array}$ & $\begin{array}{c}\text { Activity of lipase } \\
(\mathbf{U} / \mathbf{m l})\end{array}$ \\
\hline & 0 & 114 & 82 \\
$-4{ }^{\circ} \mathrm{C}$ & 10 & 108 & 77 \\
& 20 & 107 & 78 \\
$32{ }^{\circ} \mathrm{C}$ & 10 & 110 & 78 \\
& 20 & 110 & 76 \\
\hline
\end{tabular}

Electrophoresis on SDS-PAGE revealed a single band of protein corresponding to a molecular weight of $40 \mathrm{kDa}$ (Fig 3). The presence of a single band indicates that the protease and lipase produced by Bacillus licheniformis VSG1 had similar molecular weights. Protease activity was confirmed by a colorless band on blue background while lipase activity was confirmed by a yellow band on pink background (Fig 4). Both protease and lipase can thus be produced as a single mixture which will serve to fulfill the requirements of industrial processes which employ both these enzymes as bio-catalysts.

Figure 3. SDS-PAGE analysis of the purified protease and lipase

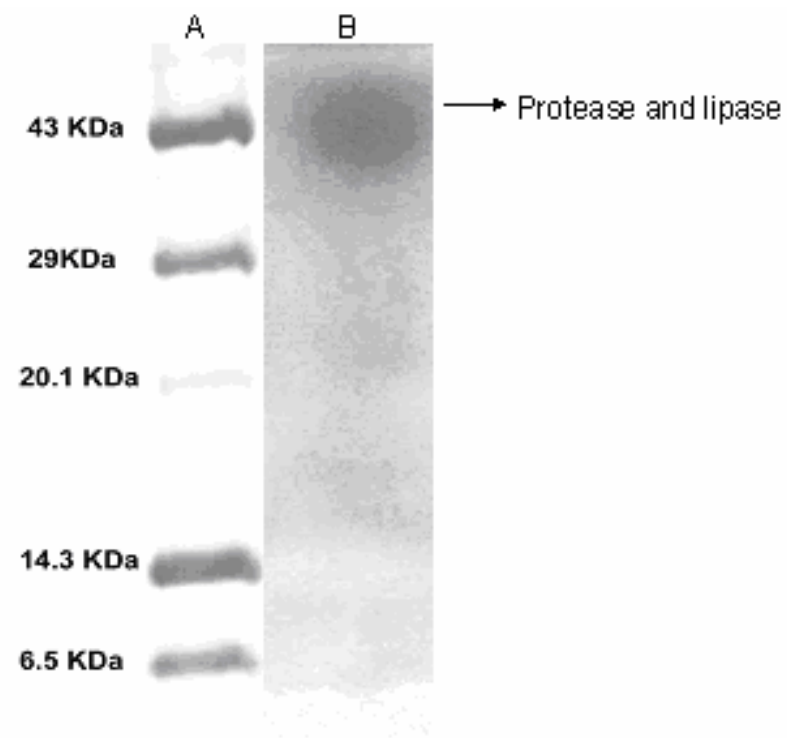

$3 \mathrm{KDa}$

Lane A: molecular weight markers;

Lane B: protease and lipase as a single band corresponding to $40 \mathrm{kDa}$
Figure 4. Zymogram of protease and lipase

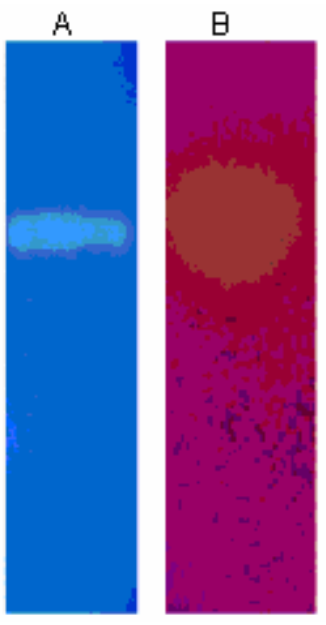

Lane A: Proteolytic activity indicated by a colorless band on a blue background;

Lane B: Lipolytic activity indicated by a yellow band on a pink background

\section{CONCLUSION}

Bacillus licheniformis VSG1 was isolated from a tannery effluent and the organism was studied for the concomitant production of protease and lipase. Both these enzymes were found to have the same molecular weight and could be produced in a single mixture and thus can be useful for many industrial processes.

\section{REFERENCES}

1. Bayoumi, R.; El-louboudey, S.S.; Sidkey, N.M.; Abd-El-Rahman, M.A. (2007). Production, Purification and Characterization of Thermoalkalophilic Lipase for Application in Bio-detergent Industry. 
J Appl Sci Res, 3(12): 1752-1765.

2. Boekema, A.B.; Breuer, M.; Hauer, B.; Koster, M.; Rosenau, F.; Jaeger, K.E.; Tommassen, J. ( 2007). Hexadecane and Tween 80 Stimulate Lipase Production in Burkholderia glumae by Different mechanisms. Appl Env Microbiol, 73, (12); 3838-3844

3. Chakraborty, K.; Raj, P.R. (2008). An extra-cellular alkaline metallolipase from Bacillus licheniformis MTCC 6824: Purification and biochemical characterization. Food Chem, 109: 727-736.

4. De Azeredo, L.A.I.; Freire, D.M.G.; Soares, R.M.A.; Leite, S.G.F.; Coelho, R.R.R. (2004). Production and partial characterization of thermophilic proteases from Streptomyces sp. isolated from Brazilian cerrado soil. Enz Microb Technol,34:354-58.

5. Frikha, B.; Kamoun, A.; Nasri, M.; (2003). Stability studies of protease from Bacillus cereus BG1. Enz Microb Technol, 32: 513-518.

6. Genckal, H.; Tari, C. (2006). Alkaline protease production from alkalophilic Bacillus sp. isolated from natural habitats. Enz Microb technol. 39, $703-710$

7. Henriette, C.; Zinebi, S.; Aumaitre, M.F.; Petitdemange, E.; Petitdemange, H. (1993). Protease and lipase production by a strain of Serratia marcescens (532 S). J Ind Microbiol, 12;129-135

8. Horikoshi, K. (1990). Enzymes of alkalophiles. In: St. Louis MO, editor. Microbial enzyme and biotechnology. 2nd ed.Amsterdam: Elsevier; p. 275-94.

9. Joshi, G.K.; Sarvesh, K.; Vinay, S. (2007). Production of moderately halotolerant, SDS stable alkaline protease from Bacillus cereus mtcc 6840 isolated from lake Nainital, Uttaranchal state, India. Braz. J. Microbiol., 38: 773-779

10. Kok, R.; Nudel, C.B.; Gonzalez, R.H.; Nugteren-Roodzant, I.M.; Hellingwerf, K.J. (1996). Physiological factors affecting production of extracellular lipase (Lip A) in Acinetobacter calcoaceticus BD413: Fatty acid repression of lip A expression and degradation of Lip A. J Bacteriol, 178:20, 6025-6035.

11. Kordel, M.; Hofmann, B.; Schomburg, C.; Schmid, R.D. (1991). Extracellular Lipase of Pseudomonas sp. Strain ATCC 21808: Purification, Characterization, Crystallization, and Preliminary X-Ray Diffraction Data. J Bacteriol, 173,15. 4836-4841
12. Laemmli, U.K. (1970) Cleavage of structural proteins during the assembly of the head of bacteriophage T4. Nature, 227, 680-685.

13. Liu, J.; Xu, Y. (2000). Enhancing effect of Tween-80 on lipase performance in enantioselective hydrolysis of ketoprofen ester. $J$ Mol Catal B: Enzym, 10;523-529

14. Lopes, M.F.S.; Leitao, A.L.; Marques, M.J.T.C.F.; Crespo, M.T.B. (1999). Processing of extracellular lipase of Lactobacillus plantarum: involvement of metalloprotease. FEMS Microbiol Lett, 483 - 487

15. Mala, B.R.; Tanksale, A.M.; Ghatge, M.S.; Deshpande, V.S. (1998). Molecular and biotechnological aspects of microbial proteases. Microbiol Mol Biol Rev. 68, 597-635

16. Nascimento, W.C.A.; Martins, M.L.L. (2004). Production and propertires of an extracellular perotease from thermophilic Bacillus sp. Braz. J. Microbiol., 35, 91-96

17. Nawani, N.; Kaur, J. (2000). Purification, characterization and thermostability of lipase from a thermophilic Bacillus sp. J33. Mol Cell Biochem, 206:91-96.

18. Olsen, H.S. (2000). Cleaning-in-place of soiled process equipment in dairy or slaughter house by circulating a solution containing a protease and a lipase .United States Patent 6071356

19. Plou, F.J.; Ferrer, M.; Nuero, O.M.; Calvo, M.V.; Alcalde, M.; Reyes, F.; Ballesteros, A. (1998). Analysis of Tween 80 as an esterase/lipase substrate for lipolytic activity assay. Biotechnology Techniques, 12(3):183-186

20. Rahman, R.N.Z.A; Geok, L.H.; Basri, M. (2005). Physical factors affecting the production of organic solvent-tolerant protease by Pseudomonas aeruginosa. Bioresour Technol, 96, 429-436.

21. Sharma. R.; Chisti, Y.; Banerjee, U.C. (2001). Production, purification, characterization, and applications of lipases. Biotechnol Adv, 19: 627-662

22. Singh. R; Gupta, N.; Goswami, V.K.; Gupta, R. (2006). A simple activity staining protocol for lipases and esterases. Appl Microbiol Biotechnol, 70: $679-682$

23. Venugopal, M.; Saramma, A.V. (2006). Characterization of alkaline protease from Vibrio fluvialis strain VM10 isolated from a mangrove sediment sample and its application as a laundry detergent additive. Process Biochem; 41:1239-43. 